\title{
Survey and Host Plant Resistance of Cultivars in Cluster Bean against Fusarium Wilt caused by Fusarium solani
}

\author{
Poonam Yadav*, R. R. Ahir, Ramesh Babu, Deepak Kumar Saini, A. Deora and Sumitra
}

Department of Plant Pathology, SKN College of Agriculture, Jobner, Jaipur, Rajasthan 303329 India

*Corresponding author

\section{A B S T R A C T}

\begin{tabular}{l} 
K e y w o r d s \\
$\begin{array}{l}\text { Fusariumsolani, } \\
\text { Fusariumwilt, } \\
\text { Cluster bean, } \\
\text { Survey, Host } \\
\text { resistance }\end{array}$ \\
\hline Article Info \\
\hline $\begin{array}{l}\text { Accepted: } \\
\text { 26 July 2020 } \\
\text { Available Online: } \\
\text { 10 August } 2020\end{array}$ \\
\hline
\end{tabular}

\section{Introduction}

Clusterbean [Cyamopsis tetragonoloba (L.) Taub.], commonly known as guar is a member of Leguminosae (Fabaceae) family and derives its name from a Sanskrit word Gauaahar which means cow fodder or otherwise fodder of the livestock. It is an important legume crop and mainly grown under rainfed condition of India during kharif and Zaid seasons. Cluster bean can be grown for different purposes viz., vegetables, green fodder, green manuring, grain and gum. Its seed health gained a great significant in recent past mainly in textiles, paper, petroleum, pharmaceuticals, food etc. Cluster bean is believed to be originated in Africa but it is grown throughout the Southern Asia since ancient times as a vegetable and fodder crop. It is widely cultivated in countries like India, Pakistan, USA, Morocco, Italy, Germany, Greece and Spain (Hymowitz and Matlock, 1963). Total area under production of guar in India is about 2.56 million ha with the production of 0.72 million tons of guar seed. Rajasthan alone contributes around 70 percent production of India. Besides Rajasthan, it is also cultivated in Haryana, Gujarat, Punjab, Uttar Pradesh and Madhya Pradesh (Pandey and Roy, 2011). In Rajasthan, cluster bean is 
cultivated throughout the state. The area, production and productivity are 35.30 million ha, 14.04 million tons and $398 \mathrm{Kg} / \mathrm{ha}$, respectively. The main guar growing districts are Bikaner, Jaisalmer, Barmer, Hanumangarh, Sriganganagar, Jodhpur, Churu, Sikar, Nagour, Jalore and Jaipur (Anonymous, 2016-17). There is no other legume crop so hardy and drought tolerant as cluster bean. Its endosperm is rich source of high-quality protein and galactomannan which is very important for the industry (Punia et al., 2009; Rai et al., 2012). This galactomannan is commonly known as guar gum and forms about 35 per cent of the dry weight of the seed. Pure guar gum contains about 80 - 90 per cent of the galactomannan (Sharma and Sharma 2013). The crop severely attacked by the vagary of disease caused by fungi, bacteria and viruses in the field. Cluster bean is attacked by several fungal pathogens which not only reduces the potency of seed, but degrades the health, beneficial and nutritional quality components. In India wilt of guar ( $F$. solani $f$. $s p$. caeruleum) is a very serious disease and was first reported by Singh (1951) from Kanpur. Mathur and Sinha (1970) reported from Uttar Pradesh that root rot of guar, an important disease, was caused by Sclerotinia rolfsii Sacc., The occurrence of Fusarium solani on guar causing root rot/wilt was reported from Rajasthan by Mathur and Shekhawat (1988). Singh and Kang (1991) reported Neocosmospora vasinfecta var. vasinfectum as the cause of wilt of guar. The pathogen causing wilt of guar in Gujarat was identified as $F$. vasinfectum and when later producing perithecia in 8-10 days old culture as Neocosmospora vasinfecta (Patel et al.,1998). Seven popular guar cultivars namely Krishna 51, B 53, Pusa Nav Bahar, Swati 55, Neelam 51, BM 83 and Amul 51 (local collection as well as from two different seed companies) were evaluated by Bohr et al., (2011). Therefore the present study was conducted to survey and identification of cultivars showing resistance/tolerant to this fungal disease in Rajasthan.

\section{Materials and Methods}

\section{Survey and collection of diseased samples}

Experimental Survey was conducted to assess the disease incidence of Fusarium wilt of cluster bean. The survey of major cluster bean growing areas in the vicinity of the Jobner which includes Nawa, Renwal, Phulera, and Jaipur tehsils (Table 1). To assess the incidence of disease, two fields randomly selected and 10 square meter area in each field in each village was marked and per cent plant mortality was observed. In the surveyed fields, per cent plant mortality/incidence was calculated by using following formula:

$$
\text { Per cent disease incidence }=\text { - }
$$

In vivo evaluation of cluster bean cultivars against fusarium wilt caused by Fusarium solani

Seed of ten cultivars of cluster bean collected from RARI, Durgapura S.K.N. College of Agriculture, Jobner and Private Companies were evaluated against wilt of cluster bean under pot conditions during kharif season 2018. Inoculum multiplied on sorghum grains was applied in pots $(20 \mathrm{~g} / \mathrm{pot})$ to increase the disease pressure. Inoculum was added before sowing. Seeds were washed thoroughly with sterilized water. Ten seeds of each cluster bean cultivar were sown in each pot. Two replications were maintained under pot conditions. Observations on disease incidence were recorded after 60 days of sowing. On the basis of disease incidence, cultivars were categorized as per criterion followed by Nagamma et al., (2015) (Table 2). 


\section{Results and Discussion}

\section{Survey and collection of Fusarium wilt of clusterbean}

Disease infected plant were collected from major cluster bean growing areas which includes Tehsils viz., Nawa, Renwal, Phulera, and Jaipur (Rajasthan) brought to the laboratory. During the survey, discussions were held with the farmers concerned, regarding occurrence and incidence of the disease. As the result of discussion, it is apparent from the data depicted in (Table 3) that Fusarium wilt incidence was observed in clusterbean surveyed areas. The disease Fusarium wilt of cluster bean incidence was recorded from 15.66 to 19.20 per cent. Wilting of plant and infected root of apical region were observed in infected plants and collected for isolation of the pathogen. The fungus was isolated in petri plates from root region tissues under aseptic condition and incubated at $25 \pm 1^{\circ} \mathrm{C}$ for 7 days. The pathogen culture was purified by single spore techniques. Survey for occurrence and distribution of disease was necessary so that In India wilt of guar ( $F$. solani f.sp.caeruleum) is a very serious disease and was first reported by Singh (1951) from Kanpur. Vir and Grewal (1973) observed in their continuous study from 1971 to 1973 that wilt of guar ( $F$. solani f.sp.caeruleum) was a serious problem and causes heavy losses to summer sown crop (April to June) under Delhi conditions. Similar observations recorded Lodha (1993) that dry root rot of cluster bean might occur at any stage of the crop from pre- emergence to maturity. Seedling blight occurs primarily on cotyledons as elongated black cankers on growing seedlings. Infected seedlings show bronzing and drooping of upper tender and parts can be easily uprooted.

Table.1 Survey areas for wilt incidence in cluster bean in the vicinity of Jobner (Jaipur)

\section{Rajasthan}

\begin{tabular}{|l|l|l|}
\hline S.No. & Tehsil & Name of village \\
\hline 1. & Nawa & $\begin{array}{l}\text { 1. Chosla } \\
\text { 2. Mundghasoi }\end{array}$ \\
\hline 2. & Phulera & $\begin{array}{l}\text { 1. Pipili ka bass } \\
\text { 2. Kalakh }\end{array}$ \\
\hline 3. & Renwal & $\begin{array}{l}\text { 1 Dungari khurd } \\
\text { 2 Harsoli }\end{array}$ \\
\hline 4. & Jaipur & $\begin{array}{l}\text { 1.Basari } \\
\text { 2.Lalpura }\end{array}$ \\
\hline
\end{tabular}

Table.2 Category for screening cluster bean cultivar against wilt incidence

\begin{tabular}{|l|c|}
\hline Category & Per cent disease incidence (PDI) \\
\hline Resistance & $0-20$ \\
\hline Moderately susceptible & $21-50$ \\
\hline Susceptible & $51-80$ \\
\hline Highly susceptible & $81-100$ \\
\hline
\end{tabular}


Table.3 Survey of wilt in cluster bean growing areas in the vicinity of Jobner

\begin{tabular}{|l|l|l|c|}
\hline S.No. & \multicolumn{1}{|c|}{ Teshil } & \multicolumn{1}{|c|}{ Name of village } & $\begin{array}{c}\text { Percent disease incidence } \\
\text { (60 days after sowing) }\end{array}$ \\
\hline 1 & Jaipur & 1. Basari & 18.30 \\
& & 2. Lalpura & 18.00 \\
\hline 2 & Nawa & 1. Chosla & 16.50 \\
& & 2. Mundghasoi & 15.66 \\
\hline 3 & Phulera & 1. Pipili Ka Bass & 16.78 \\
& & 2. Kalakh & 19.20 \\
\hline 4 & \multirow{2}{*}{ Renwal } & 1 Dungari Khurd & 18.25 \\
& & 2 Harsoli & 17.20 \\
\hline
\end{tabular}

Table.4 Evaluation of cultivars of cluster bean against Fusarium solani

\begin{tabular}{|c|c|c|c|}
\hline S.No. & Name of cultivar & Disease incidence* $(\%)$ & Reaction of cultivars \\
\hline \multirow[t]{2}{*}{1} & RGC - 197 & 51.42 & S \\
\hline & & $(45.81)$ & \\
\hline \multirow[t]{2}{*}{2} & RGC - 936 & 40.00 & MS \\
\hline & & $(39.23)$ & \\
\hline \multirow[t]{2}{*}{3} & RGC - 986 & 42.55 & MS \\
\hline & & $(40.72)$ & \\
\hline \multirow[t]{2}{*}{4} & RGC - 1003 & 37.14 & MS \\
\hline & & $(37.55)$ & \\
\hline \multirow[t]{2}{*}{5} & RGC - 1031 & 48.51 & MS \\
\hline & & $(44.15)$ & \\
\hline \multirow[t]{2}{*}{6} & RGC - 1033 & 37.14 & MS \\
\hline & & $(37.55)$ & \\
\hline \multirow[t]{2}{*}{7} & RGC - 1055 & 48.51 & MS \\
\hline & & $(44.15)$ & \\
\hline \multirow[t]{2}{*}{8} & $\mathrm{RGr}-12-1$ & 48.51 & MS \\
\hline & & $(44.15)$ & \\
\hline \multirow[t]{2}{*}{9} & $\mathrm{RL}-19$ & 42.85 & MS \\
\hline & & (40.89) & \\
\hline \multirow[t]{2}{*}{10} & RGC-1066 & 48.51 & MS \\
\hline & & $(44.15)$ & \\
\hline
\end{tabular}

* Average of two replications

Figures given in parentheses are angular transformed value.

Where, Resistance (0-20 PDI), MS- Moderately susceptible (21-50 PDI),

S- Susceptible (51-80 PDI), HS- Highly susceptible (81-100 PDI) by Nagmma et al., (2015). 
Fig.1 Evaluation of cultivars of cluster bean against Fusarium solani

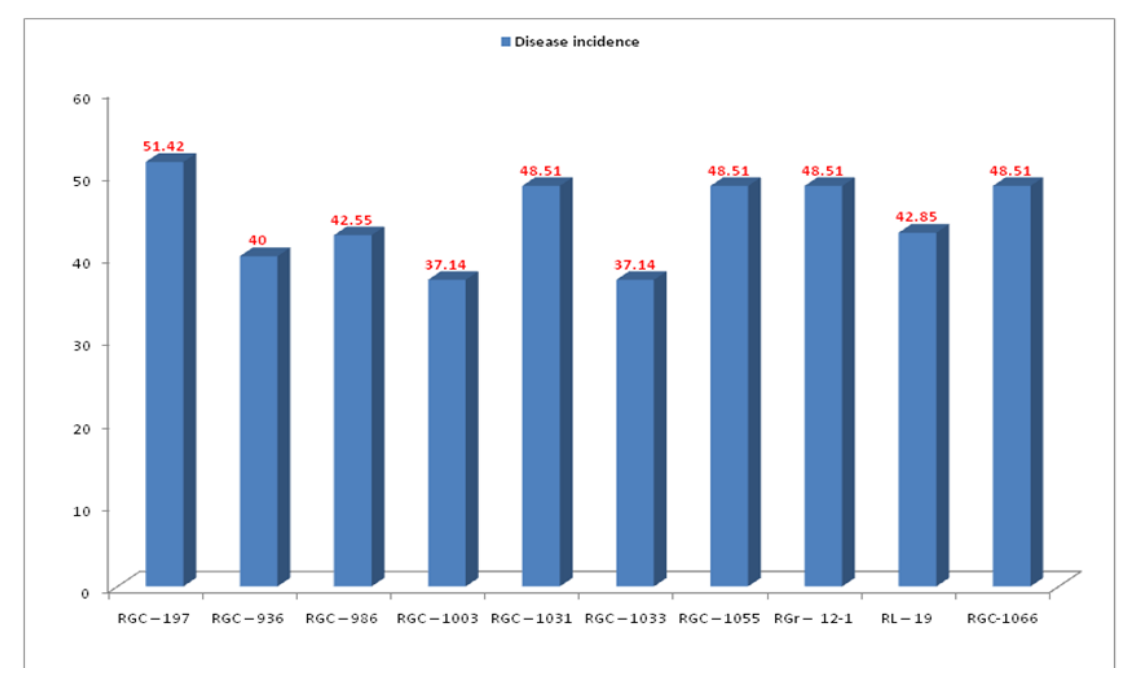

Evaluation of cultivars of cluster bean against Fusarium solani pathogen

Ten variety of clusterbean were screened against Fusarium solani under artificial inoculation conditions (Table 4). None of the variety was found immune to the wilt pathogen. Varieties, RGC -936, RGC -986, RGC -1003, RGC -1031, RGC -1033, RGC -1055, RGC - 12-1, RL -19. RGC 12-1, RL 19 and RGC -1066 were observed moderately susceptible and RGC -197 as susceptible (Figure 1). Similar results were evaluated by Bohr et al., (2011) for reaction to guar root rot pathogens $F$. solani and Rhizoctonia solani. Based on root rot incidence under inoculated (20g inoculum $\mathrm{kg}-1$ soil) conditions, Swati 55, Neelam 51, Amul 51, Krishna 51, B 53, BM 53 and PusaNavBahar were considered susceptible. This study shows that most of the available Cluster bean cultivars were susceptible to root rot pathogen and there is need to develop resistant cultivars for its suppression. The results are in agreement with Patel et al., (2002) they also evaluated genotypes of Cluster bean Genotypes GAUG 998, GAUG 9112, GAUG 605and GAUG 9010 showed moderate resistance to wilt (Neocosmospora vasinfecta) and Bajwa et al., (2000) found that out of thirty two genotypes evaluated against Fusarium wilt only one line was resistant and four lines were tolerant.

\section{References}

Anonymous.2016-17. Statistics, Directorate of Agriculture, Govt. of Rajasthan, Jaipur.

Bajwa, K M., Khan, I. A., Alam, S. S., Ahmad, I. and Gill, M. A. 2000. Screening against phytotoxins for resistance to Fusarium wilt. Pakisthan Journal of Phytopathology, 12:66-70.

Bohra, B.,Mathur, K. and Trivedi, P. C. 2011. Reaction of popular guar cultivars to Fusarium solani and Rhizoctonia solani causing root rot. Indian Phytopatholoy, 64:87-88.

Hymowitz, T. and Matlock, R. S. 1963. Guar in the United States. Okla Research Bulletin, B6. 11:1-34.

Lodha, S. 1993. Fighting dry root rot of legumes and oilseeds. Indian Farming, 43: 11-13.

Mathur, S. B. and Sinha, H. 1970. Role of manuring in control of root rot of guar (Cyamopsis psoralioides dc.) and wilt of gram (Cicer arietinum L.) caused by Sclerotium rolfsii Sacc. Mycopath Mycology Application, 40:155-59. 
Mathur, K. and Shekhawat, K.S. 1988. Fusarium root rot of guar. Indian Journal of Mycology Plant Pathology, 17: 237.

Punia., A, Yadav., R, Arora., P. and Chaudhury., A. 2009. Molecular and morpho-physiological characterization of superior cluster bean (Cymopsis tetragonoloba) varieties. Journal of Crop Science and Biotechnology, 12:143-148.

Pandey, K. C. and Roy, A. K. 2011. Forage crops varieties. Pp. 66- 68. Indian Grassland and Fodder Research Institute, Jhansi, Uttar Pradesh, India.

Patel, D. S., Patel, S. I. and Desai, A.G. 2002.
Cluster bean varietal to wilt disease caused by Neocosmospora vasinfecta E.F. Smith. Indian Journal of Mycology Plant Pathology, 32:120-21.

Patel, D. S., Patel, S. I., Desai, B. G. and Khandar, R. R. 1998. Neocosmospora vasinfecta an incitant of wilt of cluster bean. Indian Phytopatholoy, 51:305.

Singh, R. S. (1951). Root rot of guar. Sci Cult. 17:131-34.

Vir, S. and Grewal J. S. 1973. Studies on the physiology of Fusarium caeruleumthe causal organism of guar wilt. Indian Phytopatholoy, 26:72-75.

\section{How to cite this article:}

Poonam Yadav, R. R. Ahir, Ramesh Babu, Deepak Kumar Saini, A. Deora and Sumitra. 2020. Survey and Host Plant Resistance of Cultivars in Cluster Bean against Fusarium Wilt caused by Fusarium solani. Int.J.Curr.Microbiol.App.Sci. 9(08): 3680-3685. doi: https://doi.org/10.20546/ijcmas.2020.908.425 